\title{
$(4$ norden
}

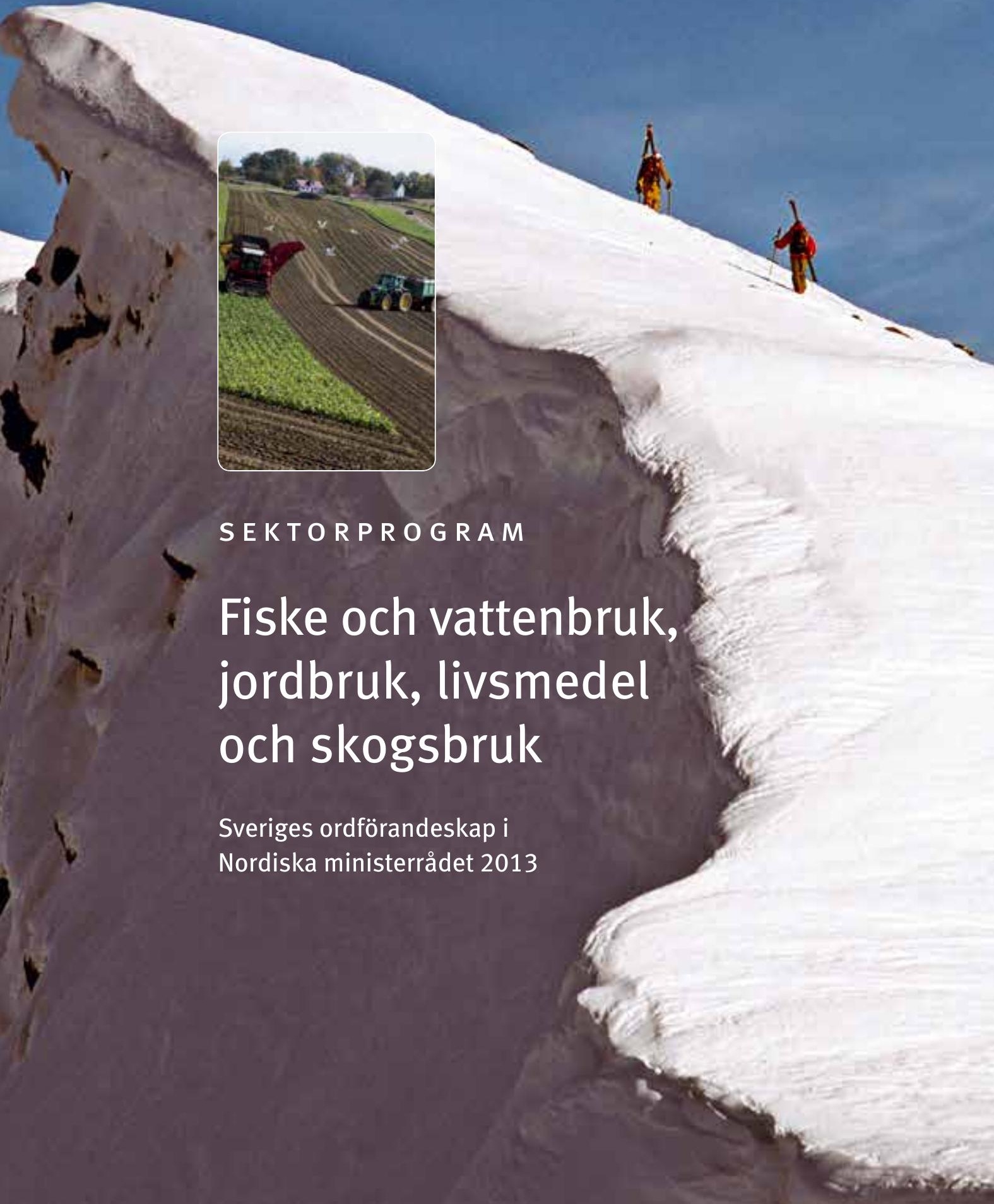


Fiske och vattenbruk, jordbruk, livsmedel och skogsbruk

Program för Sveriges ordförandeskap i Nordiska ministerrådet 2013

ISBN 978-92-893-2421-2

http://dx.doi.org/10.6027/ANP2012-756

ANP 2012:756

C Nordiska ministerrådet, Köpenhamn 2012

Design: Jette Koefoed/Nordiska ministerrådet

Foto: s. 4: Johnér Bildbyrå AB / Ewa Ahlin,

s. 6: Etsabild AB / Kari Kohvakka, s. 8: Naturbild AB / Lina Karna Kippel,

s. 7: Anna-Karin Nyman, s.13: Naturbild AB / Malcolm Hanes,

s. 15: Johnér Bildbyrå AB / Henrik Trygg

Upplaga: 500

Tryck: Rosendahls-Schultz Grafisk

Printed in Denmark

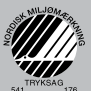

Nordiska ministerrådet

Ved Stranden 18

DK-1061 København K

Telefon (+45) 33960200

www.norden.org

\section{Det nordiska samarbete}

Det nordiska samarbetet är ett av världens mest omfattande regionala samarbeten. Det omfattar Danmark, Finland, Island, Norge och Sverige samt Färöarna, Grönland och Åland.

Det nordiska samarbetet är politiskt, ekonomiskt och kulturellt förankrat och är en viktig partner i europeiskt och internationellt samarbete. Den nordiska gemenskapen arbetar för ett starkt Norden i ett starkt Europa.

Det nordiska samarbetet skall stärka nordiska och regionala intressen och värderingar i en global omvärld. Gemensamma värderingar länderna emellan bidrar till att stärka Nordens ställning som en av världens mest innovativa och konkurrenskraftiga regioner. 
IIIII norden 

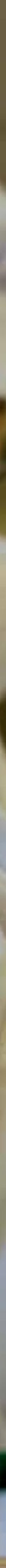


\section{norden}

SEKTORPROGRAM

Fiske och vattenbruk, jordbruk, livsmedel och skogsbruk

Sveriges ordförandeskap i Nordiska ministerrådet 2013 



\section{Förord}

Landsbygdens värden behövs, nu och i framtiden. Här har vi friluftslivet runt knuten, förnybar energi och klimatsmart byggmaterial. Här finns den hållbart producerade maten och de goda livsmiljöerna.

Inom Norden har vi mycket gemensamt: klimat, natur och kultur och en likartad inställning till livet och välfärden.

Ofta delar vi samma utmaningar och vi har i mångt och mycket samma möjligheter. Inte minst gäller detta landsbygdsfrågorna.

Under Sveriges ordförandeskap inom det Nordiska ministerrådet för fiske och vattenbruk, jordbruk, livsmedel och skogsbruk vill jag tillsammans med mina nordiska kollegor fokusera på hur vi tillsammans kan hitta de goda idéerna, exemplen och arbetssätten som ser till att vår landsbygd fortsätter att vara levande.
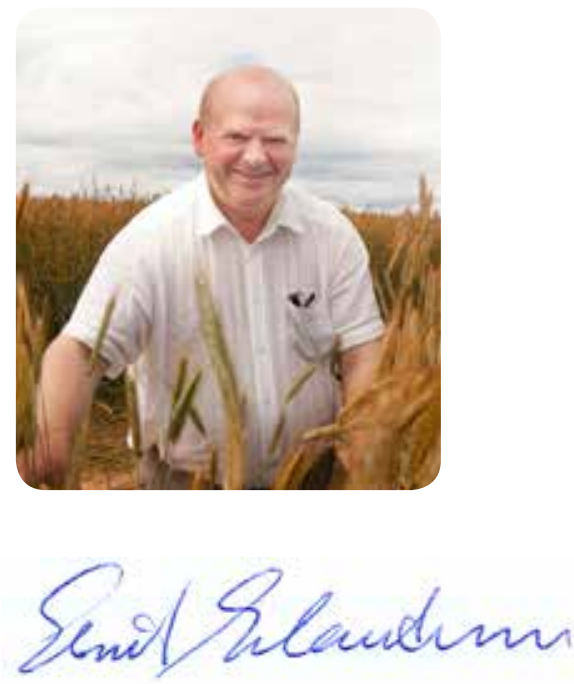

Eskil Erlandsson

Landsbygdsminister 

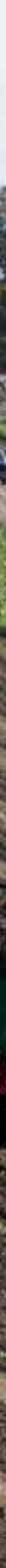

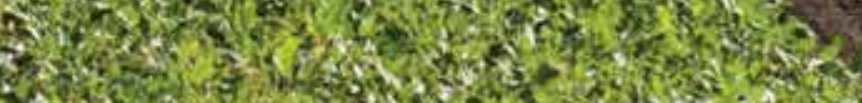

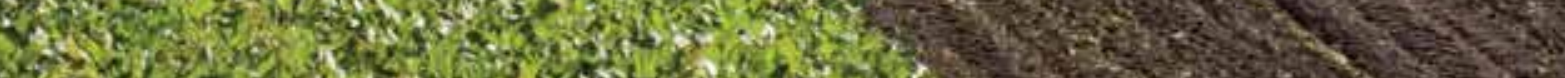

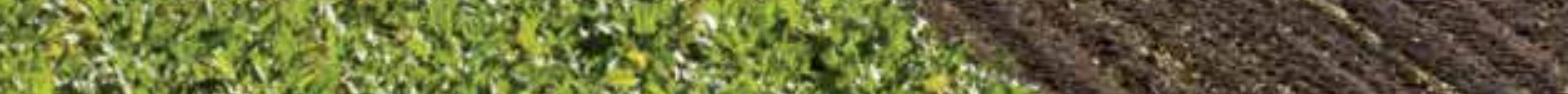

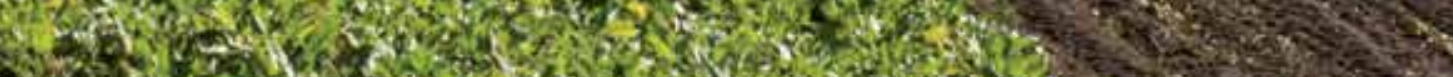
2)

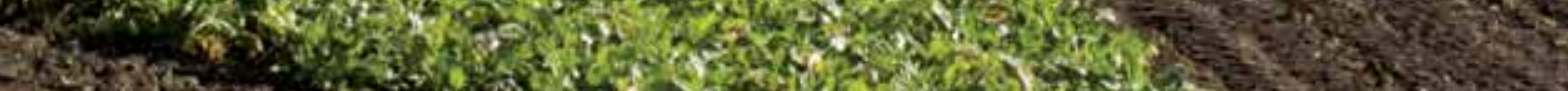

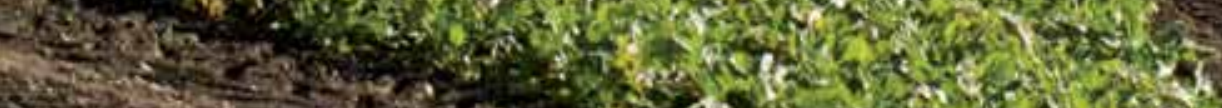

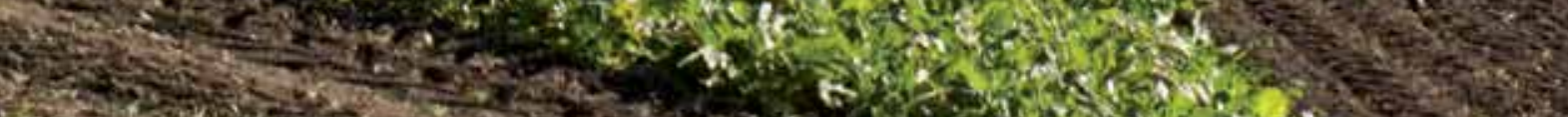

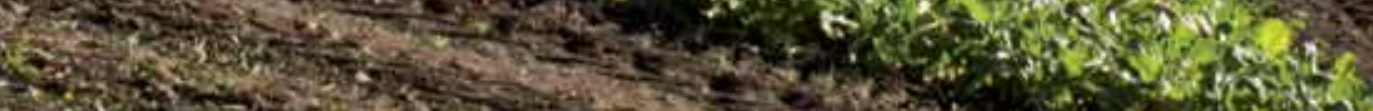

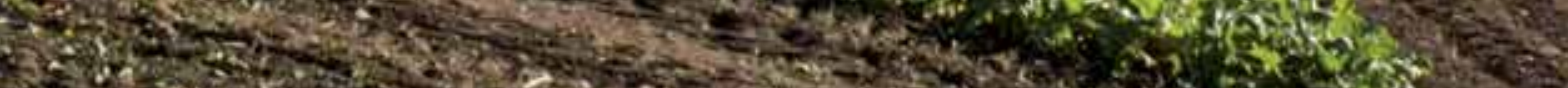

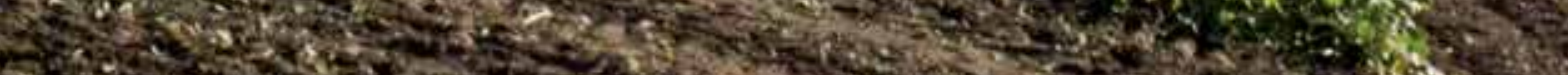
Q

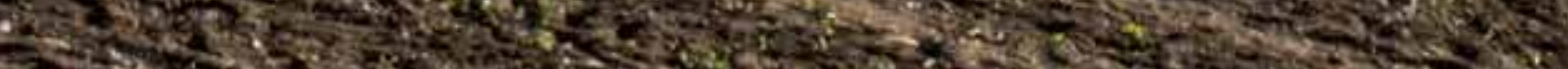

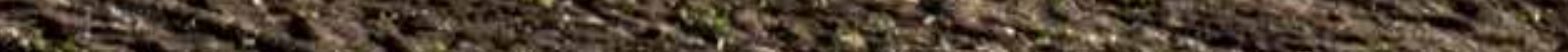

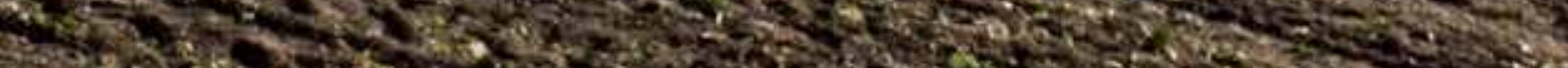

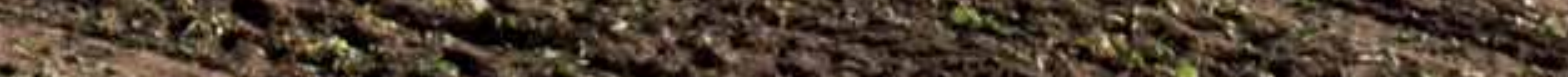

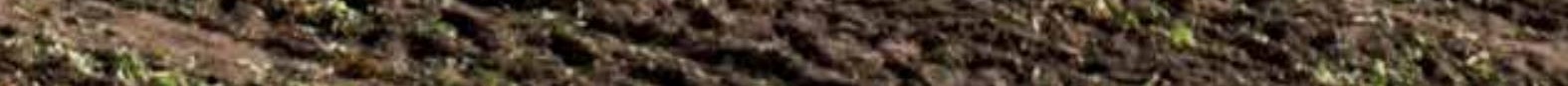




\title{
Den moderna landsbygden
}

\author{
Vad erbjuder Nordens areella näringar - fiske och vattenbruk, jord- \\ bruk, livsmedel (inklusive djurvälfärd och folkhälsa) och skogsbruk - \\ för möjligheter i en ny tid?
}

Nordiska ministerrådet för fiskeri och vattenbruk, jordbruk, livsmedel och skogsbruk (MR-FJLS) har som huvudsakliga uppgifter att främja en hållbar användning av naturresurser och genetiska resurser, möta klimatförändringen och dess utmaningar, stödja en hållbar utveckling av kust- och landsbygd samt främja sunda och säkra livsmedel. Utifrån dessa perspektiv ska MR-FJLS bidra till att öka Nordens konkurrenskraft och därmed skapa en positiv utveckling för Norden.

En tydlig målsättning för det svenska ordförandeskapet är att hela regionen ska leva och att det ska vara möjligt att bo och verka på en levande landsbygd med konkurrenskraftiga villkor, men också att landsbygdens potential till att bidra till grön tillväxt ses och tas tillvara. Detta förutsätter en hållbar produktion miljömässigt, socialt och ekonomiskt. Fokus för ordförandeskapet är framtiden: det vill säga att lyfta fram de områden som finns, men bara är i början av dess kapacitet och de områden som knappt lämnat ritbordet. Låt bygdegården vara high-tech och skapa medvetenhet om de stora förändringar vi står inför och de möjligheter som finns. Låt oss prata om en biobaserad samhällsekonomi, hållbart resursutnyttjande och matvanor i en modern tid - det vill säga modern landsbygd!

\section{Jordbruk och skogsbruk}

Det nordiska jord- och skogsbrukssamarbetet ska konkretisera och förverkliga en hållbar utveckling inom den gröna sektorn. Samarbetet fokuserar på att främja ett hållbart nyttjande av naturresurser och en hållbar utveckling av jordbruksproduktionen under påverkan av globalisering, miljö och klimatförändringar samt att verka för en levande och konkurrenskraftig landsbygd. 
Livskraftiga företag och ett diversifierat näringsliv är avgörande för en levande landsbygd och utvecklingskraft i hela Norden. I en global och alltmer konkurrensutsatt ekonomi är tillgång till ny kunskap och företagens möjlighet till nyttiggörande av kunskapen mycket viktigt.

En modern landsbygd kräver nya, lokalt baserade men globalt anpassade, lösningar där entreprenörer utvecklar nya vägar för att utveckla sina egna företag och därmed den lokala ekonomin. Förutsättningarna för entreprenörskap och innovation behöver stärkas i landsbygdsområden, för att nya företag ska etableras och för att befintliga företag ska utvecklas. Sammantaget kan dessa företag ge ny sysselsättning på landsbygden och bidra till hela landets innovation och tillväxt. En konferens på detta tema kommer att anordnas i syfte att medverka till starkare lokala ekonomier och visa på de bästa exemplen hur man lokalt kan agera för att utveckla den egna ekonomin genom att samla och kanalisera resurser till lokala investeringar.

Arbetet inom Ny Nordisk Mat fortsätter som en inspirationskälla för landsbygdsutveckling genom matföretagande och turism under det svenska ordförandeskapet. Deltagande i Nordisk Scenkonstfestival i Washington kommer att bidra till att sätta Norden och Ny Nordisk Mat på världskartan.

Ett pilotprojekt för offentligt-privat partnerskap (PPP) för växtförädling etablerades 2010 efter en genomlysning av växtförädlingen i Norden. Pilotprojektet kom i gång 2011 och sträcker sig fram t.o.m. 2013. Projektet är en bro mellan forskning och näringsliv. Arbetet kommer att utvärderas under det svenska ordförandeskapet.

En viktig del i förädlingsarbetet på jord- och skogsbruksområdet är tillgången till genetiska resurser. Arbetet med att ta hand om och bevara den genetiska variation, de genetiska resurserna, är en försäkring för framtiden. Genetiska resurser utgör basen för möjligheten till anpassning av både växter och djur till nya förhållanden som klimatförändringar, nya sjukdomar och insektsangrepp samtidigt som man utnyttjar nya kommersiella sorters fördelar. Detta är och förblir en prioriterad fråga $\mathbf{i}$ det nordiska samarbetet.

Statsministrarnas initiativ om Grön tillväxt fordrar en aktiv samverkan med de areella näringarna. Det handlar bland annat om användning av förnybara råvaror för industrin och om forskning för en biobaserad samhällsekonomi. En hållbar jordbruks- och livsmedelsproduktion med minskade utsläpp av växthusgaser är en viktig prioritering. Detta 
kräver även att produktionen av biomassa sker i samklang med kraven på biologisk mångfald och hållbar markförvaltning. Den biobaserade basindustrin måste utvecklas för att möta framtidens utmaningar. Detta kan främjas genom förenade krafter inom forskning och utveckling på nordisk nivå.

I omställningen till en biobaserad samhällsekonomi utgör skogen och skogsråvaran basen tillsammans med råvara från övriga areella näringar. Förutom de traditionella produkterna som virke, papper och pappersmassa kan dessa råvaror utgöra nya konstruktionsmaterial. Trä som material vid bostadsbyggande är klimatsmart och förnybart. Ökat förädlingsvärde ur biomassan skapas genom gynnsamma miljöer för såväl företagande som forskning och innovation.

Dessutom är det viktigt att lyfta fram skogens sociala värden med rekreation och turism. Det finns en stor outnyttjad potential inom turistområdet och upplevelsebaserade näringar. Genom att förstärka marknadsföringen av såväl redan etablerade som nyutvecklade resmål kan turism öka och bidra till att jobb stannar och skapas på landsbygden.

Skogen, skogsnäringen och dess värdekedja är centrala element för välståndet i Norden. Dessutom främjar skogsmiljön hälsa och välbefinnande genom friluftsliv och turism och är viktig för bevarande av biologisk mångfald och processer kopplade till klimat och vattenkvalitet. Det nordiska skogssamarbetet fokuserar på att främja ett hållbart nyttjande av skogen och en hållbar utveckling av skogsbruket och dess värdekedja.

Prioriteringen under det svenska ordförandeskapet 2013 är att vid en konferens utveckla skogens roll i en modern, biobaserad samhällsekonomi. Syftet med konferensen är att förmedla kunskap och att inspirera entreprenörer kring skog och trä, där träbyggnad är en väsenlig del, både regionalt (nordiskt) och lokalt. I den svenska regeringens satsning Skogsriket är träbyggande ett av de prioriterade områdena och tillsammans med övriga nordiska länder kan vi samverka, lyfta goda exempel och bygga nätverk.

\section{Fiske}

Sverige driver sedan länge på för att förbättra fiskeriförvaltningen i riktning mot ett långsiktigt hållbart resursutnyttjande och en minskning av fiskets ekosystemeffekter. Arbetet inom MR-FJLS kommer under året att 
särskilt uppmärksamma två aspekter som båda är centrala för det nordiska fisket, men också av betydelse för fisket i Europa och resten av världen: flerartsförvaltning och bränslesubventioner till fiskefartyg.

Flerartsförvaltning är en nödvändig förutsättning för ekosystemförvaltning som är ett sedan länge eftersträvat mål för fiskeriförvaltningen. Utgångspunkten är att beaktande av alla delar av det marina ekosystemet ger en skarpare och effektivare förvaltning än om varje fiskart behandlas var för sig. De biologiska problemen är stora, men har nu lösts för tre arter i Östersjön som kommer att bli föremål för den första flerartsförvaltningen någonsin åtminstone i Europa. Ett seminarium kommer att äga rum under våren 2013 i samarbete med Internationella havsforskningsrådet (ICES), som ansvarar för det vetenskapliga arbete som ligger till grund för fiskeriförvaltningen i Europa. Mot bakgrund av erfarenheterna inom främst ICES, kommer seminariet att omfatta dels en öppen diskussion, dels ett utarbetande av praktiska riktlinjer för flerartsförvaltning med sikte även på engelsktalande användare.

Bränslesubventioner för fartyg och flyg är en betydande källa till växthusutsläpp. Det nordiska fisket är inget undantag. För att underlätta politiska bedömningar och beslut av de ekonomiska effekterna av en utfasning av subventionerna - vilket är ett förslag inom bland annat Världshandelsorganisationen - har Sverige initierat ett nordiskt projekt för att ekonometriskt illustrera dessa effekter på nationell nordisk basis. Projektet beräknas vara avslutat under senare delen av hösten 2013 och blir då föremål för ett nordiskt seminarium.

\section{Livsmedel}

Säkra, sunda och tillräckliga livsmedel är en förutsättning för människors hälsa och sociala trygghet. Främjande av hälsa och välbefinnande, bland annat genom tillgång till friluftsliv i en rik natur och en levande matkultur, är viktiga delar i den nordiska välfärdsmodellen. Det svenska ordförandeskapet vill genom det nordiska samarbetet fortsätta vidareutveckla den nordiska välfärdsmodellen med tonvikt på god folkhälsa, djurhälsa och konsumentskydd.

En viktig fråga inom livsmedelsområdet under Sveriges ordförandeskap är publiceringen av de reviderade nordiska näringsrekommendationerna (NNR 5). De föregående NNR från 2004 baserades på aktuell vetenskap och forskning och tog hänsyn till matvanor och hälsoförhållanden i de 


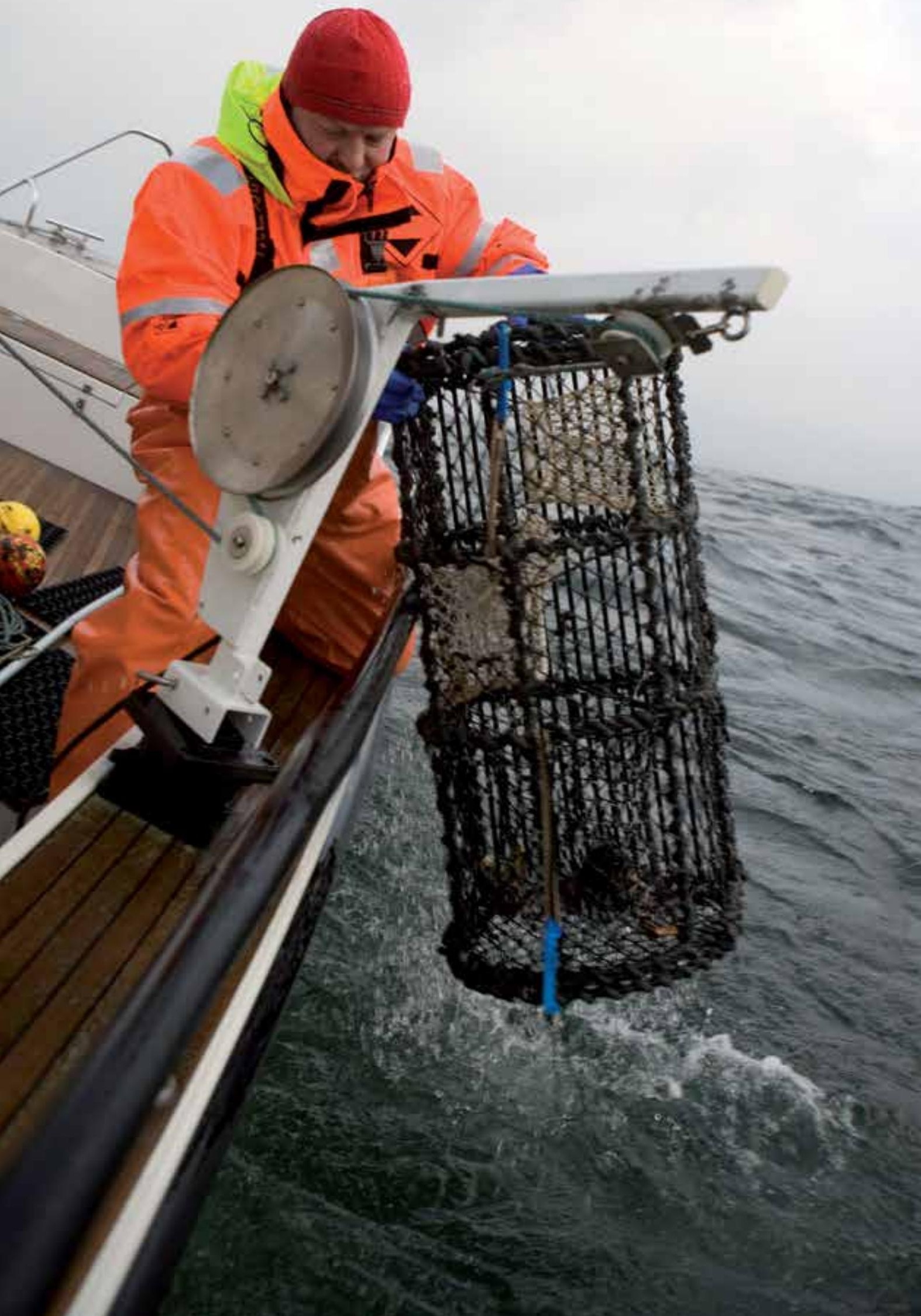


nordiska länderna. Nya områden som nu tas upp är fysisk aktivitet och livsmedelsbaserade rekommendationer för att ge en översikt av kunskapsläget om sambandet mellan konsumtion av några livsmedelsgrupper och risken för att utveckla olika sjukdomar.

Under temat "Moderna människans matvanor" planerar vi en konferens våren 2013 om vad den moderna människan i framtiden vill och kan äta och som sätter måltiden i ett brett perspektiv, med fokus på folkhälsa, miljöpåverkan och etik. Syftet med konferensen är att förmedla kunskap och påverka beslutsfattare rörande våra livsmedel, måltider, matvanor och potentialen i livsmedelsbranschen. Vi vill bland annat lyfta fram moderna matvanor och hållbar konsumtion. Det nordiska köket är numera en internationell trend och inspirationskälla, men hur äter vi i Norden och vilken betydelse har det för folkhälsan? Hur kommer de reviderade nordiska näringsrekommendationerna, som ska lanseras våren 2013, att påverka den moderna måltiden, matsedeln och menyn? Att Norden ska bli ledande i att minska matsvinn är också prioriterat.

MR-FJLS antog 2006 den nordiska handlingsplanen för kost och motion, som handlar om bättre hälsa och livskvalitet genom mat och fysisk aktivitet. Med denna handlingsplan underströk de nordiska ministrarna vikten av att arbeta för bättre hälsa och en ökad livskvalitet på lika villkor för alla nordiska medborgare. Det är nu aktuellt att följa upp denna plan och eventuellt revidera den.

Sverige planerar också att arrangera ett expertgruppsmöte om dricksvatten hösten 2013 samt en workshop kring begreppet One Health, dvs. sambandet mellan djurs och människors hälsa särskilt med tanke på antibiotikaresistens, där även djurvälfärd inkluderas.

\section{Summering}

Ordförandeskapet och alla dess aktiviteter ska utgöra en helhet, fastställd genom sektorsprogrammet och verkliggjord genom ett väl sammanhållet aktivitetsprogram, där prioriteringarna ska ge såväl nordisk som svensk nytta. Med utgångspunkt i befintligt och kommande ramprogram för MR-FJLS har ett övergripande tema/prioritering för Sveriges ordförandeskap i MR-FJLS fastställts - Den moderna landsbygden. 


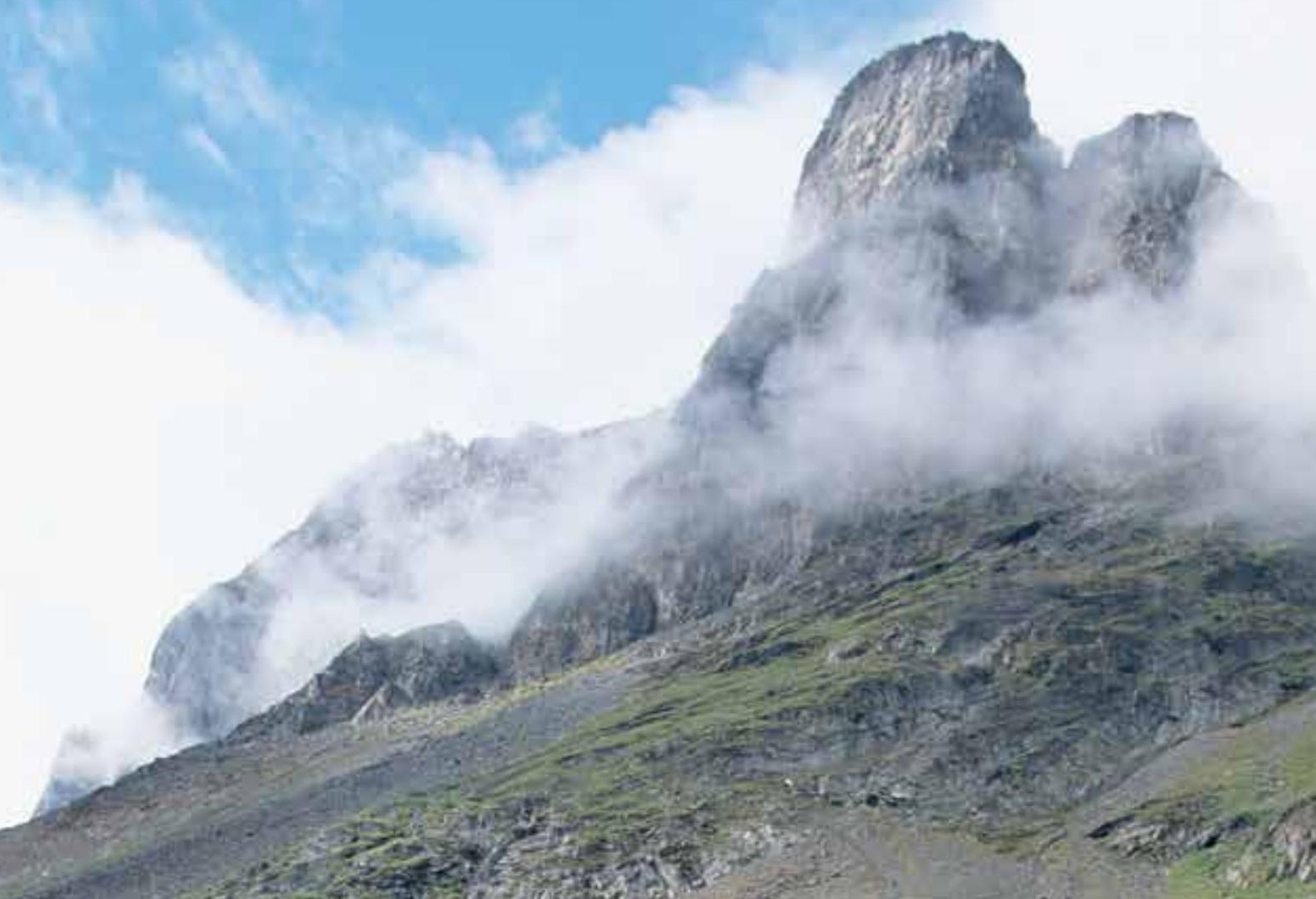
(2)

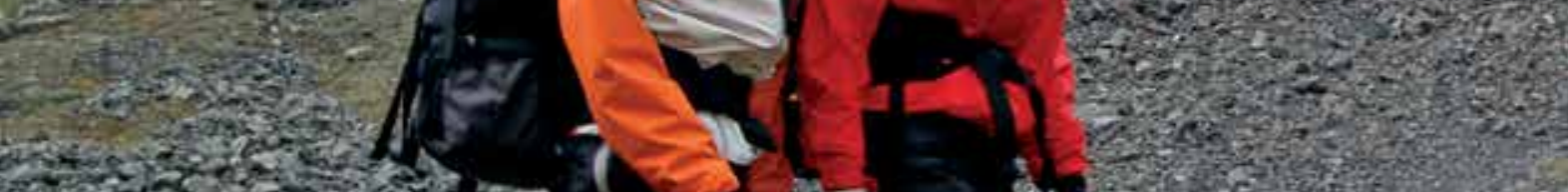

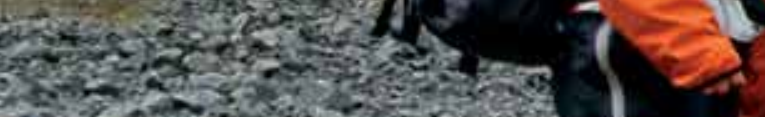

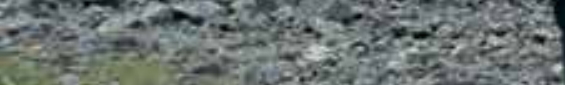

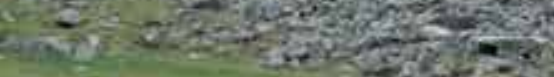

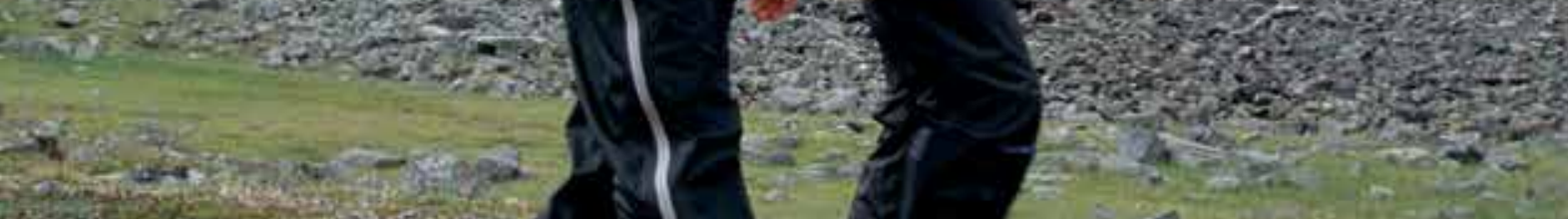

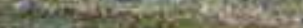

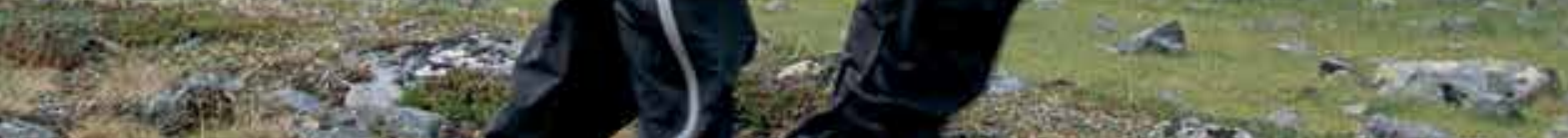

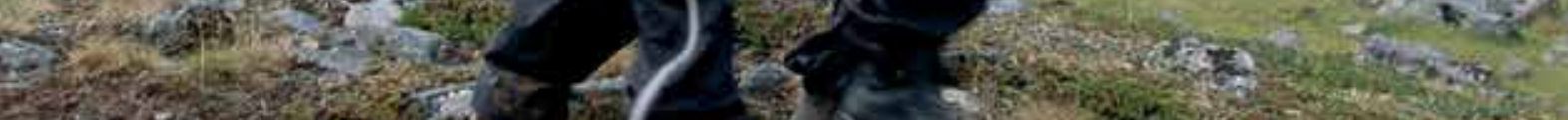

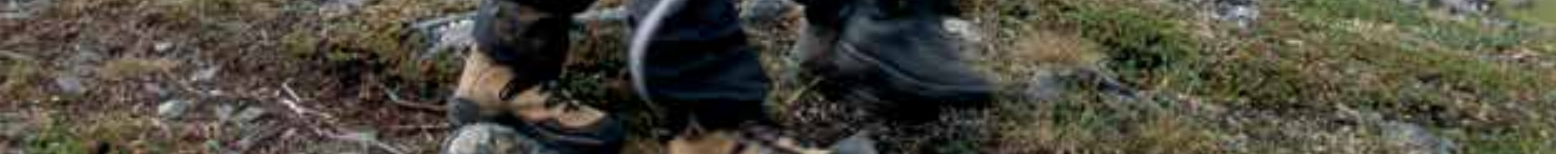

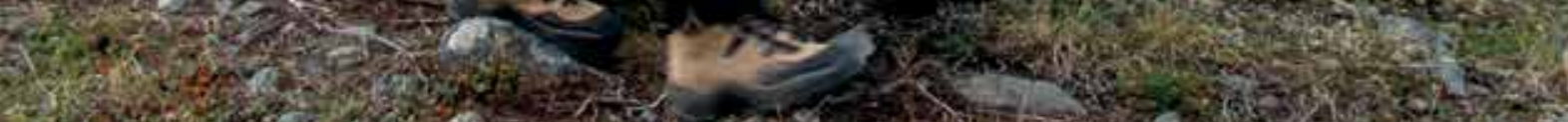

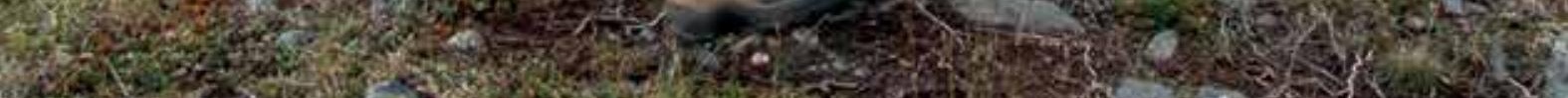

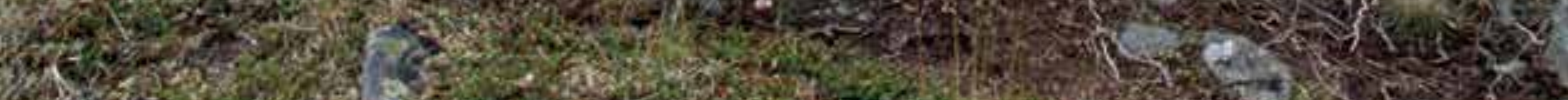
(2)

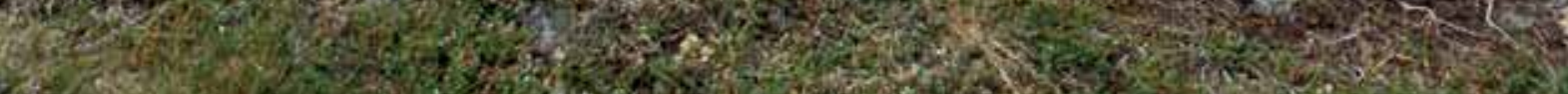
6.

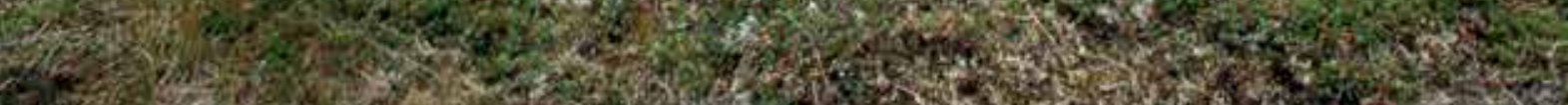

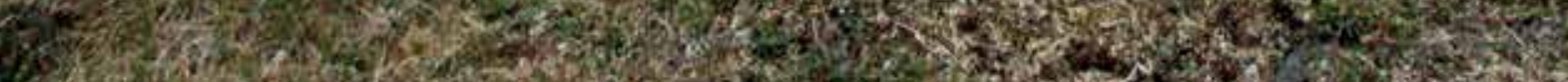
(4) Fe- 


\section{norden}

Nordiska ministerrådet

Ved Stranden 18

DK-1061 København K

www.norden.org

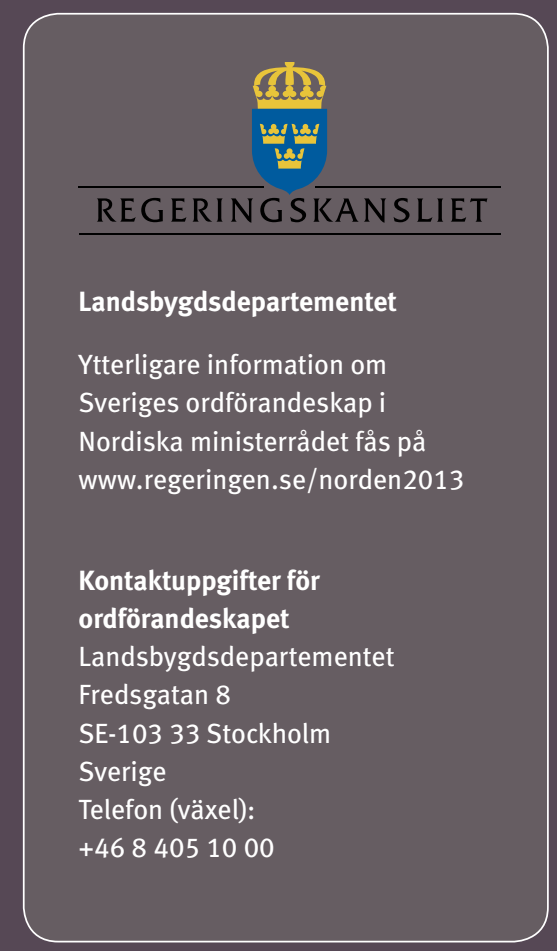

